\title{
An Analysis of Evolution from Traditional To Green Supply Chain
}

\author{
Pravin B. Kale \\ Department of Computer Engineering, Government Polytechnic, Jintur, \\ Yeldari Road, Jintur Dist.Parbhani-413509
}

Received on: 11 December, 2020, Revised on: 10 January, 2021, Published on: 16 January, 2021

\begin{abstract}
Today, one of the top priorities of an organization's modern corporate strategy is to portray itself as socially responsible and environmentally sustainable. As a focal point of sustainability initiatives, green supply chain (GSC) management has emerged as a key strategy that can provide competitive advantages with significant parallel gains for company profitability. In designing a GSC, the purpose is adoption of comprehensive and cross-business sustainability principles, from the product conception stage to the endof-life stage. GSC is an increasingly important aspect in today's supply chain practices. Meeting environmental concerns in industrial operations has evoked interest among environmentalists, government bodies, academics and business organisations in recent years.

GSC focuses not only on cost, efficiency and high customer service, but also on low environmental consequences. This paper provides the unique characteristics of GSC and discussed the main stages of the evolution from the traditional supply chain to GSC. This paper presents the evolution of traditional supply chains and their management from its origins to the most recent transition to green supply chains. Supply chain management attempts to assess all the components of a supply chain, such as information and material flows. The need for supply chain management triggered the birth and evolution of both industrial engineering and operations research. In a conventional supply chain, a product's journey starts from the raw material supplier. Then the manufacturer converts the materials into finished or semi-finished products, which are then brought to the distributors or the wholesalers. The combination of the lean and the agile supply chains resulted in the development of the hybrid supply chain to meet the requirements of hybrid products. Supply chains
\end{abstract}

have been always considered as the procedures used to transform raw materials to finished products which are then delivered to consumers. Private corporations, under certain circumstances, are also highly interested in planning and implementing green strategy. It focused also on numerous advantages in redefining a conventional supply chain and evolving it to GSC management.

Keywords- GSC, supply chain, manufacturer, environmental.

\section{I- INTRODUCTION}

$\mathbf{T}_{\mathrm{h}}$ his section provides the unique characteristics of green supply chain and discusses the main stages of the evolution from the traditional supply chain to the green supply chain. Green supply chain focuses not only on cost, efficiency and high customer service, but also on low environmental consequences. In early environmental management frameworks, operating managers were involved only at arm's length. Separate organizational units had responsibility for ensuring environmental excellence in product development, process design, operations, logistics, marketing, regulatory compliance and waste management. Today, this has changed. As in the quality revolution of the 1980s and the supply-chain revolution of the 1990s, it has become clear that the best practices call for integration of environmental management with ongoing operations. Green supply- 


\section{International Journal of Innovations in Engineering and Science, www.ijies.net}

chain management (GSCM) is gaining increasing interest among researchers and practitioners of operations and supply chain management. The growing importance of GSCM is driven mainly by the escalating deterioration of the environment, e.g. diminishing raw material resources, overflowing waste sites and increasing levels of pollution. However, it is not just about being environment friendly; it is about good business sense and higher profits. In fact, it is a business value driver and not a cost centre (Wilkerson 2005). In addition, the regulatory requirements and consumer pressures are driving GSCM. Hence, the scope of GSCM ranges from reactive monitoring of the general environment management programmes to more proactive practices implemented through various R's (Reduce, Re-use, Rework, Refurbish, Reclaim, Recycle, Remanufacture, Reverse logistics, etc.)

\section{II- LITERATURE REVIEW}

Sufficient literature exists about various aspects and facets of GSCM. Wu et al., (2012) studied the practices GSCM practices adopted by the largest companies of the world. Data were collected through review of published reports that may contain corporate sustainability practices, including social responsibility reports, corporate citizenship reports, and sustainability reports. Preventing pollution and Cost reduction were two main reasons for Multinational Corporations to adapt GSCM. Yazdani M. (2014) examined to set criteria on which green supplier can be selected from a number of suppliers available in the automobile manufacturing sector of Spain. The Green supplier selection was done through fuzzy multi criteria decision making (MCDM).Data were collected from automobile expert judgments using structured questionnaire, in depth interviews and detailed literature review. The results showed that green material and green design were most dominant factors affecting green supplier selection. Nawire et al., (2014) studied the effects of implementing GSCM on procurement performance in Kenya sugar industry. Data were analyzed by using factor analysis and regression which showed the $\mathrm{R}$ square value of $62.7 \%$. The results showed that green purchasing and green manufacturing had a positive direct impact on procurement performance within sugar sector. Chiu et al.(2014) investigated the best possible solution for green supply chain with environmental concerns. Data were analysed through fuzzy integrated logistics with transportation cost and demand fuzziness to resolve GSCM under risky environment. Outcomes of the study indicated that increase in Government subsidy also increased profits for reverse logistics.

Earlier works and reviews have a limited focus and narrow perspective. They do not cover adequately all the aspects and facets of GSCM. Much of the work is empirical and does not focus adequately on modelling and evolution of GSCM. Our objective is to present a comprehensive integrated view of the GSCM evolution on all the aspects and facets of GSCM, taking a 'reverse logistics angle' so as to facilitate further study, practice and research.

To meet this objective, we define a few relevant terms in this section. Either these have been taken from the existing literature, or we define them appropriately. The second section portrays the research methodology applied. We also map the tools/techniques vis-à-vis the problem context classification. Finally, we provide a timeline indicating relevant papers for the benefit of academicians, researchers and practitioners. At the end of the paper, we draw certain conclusions and identify potential issues and opportunities in the realm of GSCM.

\section{III - RESEARCH METHODOLOGY}

The objective of this paper is to identify major works on evolution of green supply-chain management research integrating environmental thinking into supply-chain management, and thereafter, to classify them so as to identify gaps, issues and opportunities for further study and research. A literature review seems to be a valid approach, as it is a necessary step in structuring a research field and forms an integral part of any research conducted (Easterby-Smith et al. 2002). This helps to identify the conceptual content of the field (Meredith 1993) and guides towards theory development. Our research is driven by theoretical pre considerations and follows a clear process, as this allows conclusions to be drawn on the reviewed literature. It may be classified as an archival research method in the framework for conducting and evaluating research suggested by Searcy and Mentzer (2003). Our process of analysis comprises the following steps:

\section{A. Supply chains in ancient times}

In ancient times, manufacturing of goods was directly dependent on the accessibility of raw materials, while their moving was obstructed by limitations in transportation technology. As a result, most of the products were produced and consumed at a local level, without major transportation requirements. Also, since 


\section{International Journal of Innovations in Engineering and Science, www.ijies.net}

transportation of goods was an expensive process, it was limited to the most valuable goods, such as gold and weapons. Supply chains were simple, restricted mainly to the immediate interactions between producers and consumers. However, the concepts of logistics and supply chain management were being applied even from the ancient times. A representative example is the one of Alexander the Great, whose impressive achievements were not only based on his army's competence, but above all on the application of primary - but very efficient - management of his supply chain. For instance, Alexander's the Great army camped near rivers or seaports in order to facilitate the transportation of substantial amounts of supplies from other areas of his empire. According to the historian Donald Engels, Alexander the Great planned his moves and managed his army taking advantage of the strong parts of his army's supply chain. In the last 100 years, supply chains have been evolving in order to respond to current, everchanging market needs. In the material to follow within this chapter, we aim to present the evolution of traditional supply chains and their management from its origins to the most recent transition to green supply chains. We also attempt to explain the motivators of this transition.

\section{B. The origins of supply chains}

As mentioned earlier, supply chains have been applied even from the ancient years. In the last century, supply chains have been developed and adjusted to meet the global market needs. More specifically, in the beginning of the 20th century, improvements in supply chain management aimed at facilitating processes that required a large amount of workforce. Today, supply chains can be extremely complicated, involving an immense number of stakeholders with different expectations and needs, from raw material manufacturers to end customers. Thus, modern supply chains require a more strategic and integrated management for their efficient operation. Supply chain management attempts to assess all the components of a supply chain, such as information and material flows. The need for supply chain management triggered the birth and evolution of both industrial engineering and operations research. During the 1910s, Fredrick Taylor, who is considered the father of industrial engineering, aimed his study on the improvement of hand-operated loading procedures. The complex needs of army supply chain management in the Second World War during the 1940s led to the development of operation research and the recognition of analytics as a valuable tool for the relevant studies.
When put together, industrial engineering and operation research can provide effective solutions regarding supply chain and logistics issues.

\section{The evolution of supply chains}

In a conventional supply chain, a product's journey starts from the raw material supplier. Then the manufacturer converts the materials into finished or semi-finished products, which are then brought to the distributors or the wholesalers. Then, based on the market demand, products are sold to the retailers, and finally they end up with the final customers/consumers. The previously mentioned procedures, with the involvement of all relevant stakeholders (i.e. suppliers, manufacturers, forwarders, retailers, customers, etc.) constitute a supply chain

Over the years, market expansion and globalization led to the consequent evolution of supply chains and their management. Companies need to respond to a variety of challenges, especially in a constantly changing global market. Over recent decades, international trade has evolved rapidly. Customers get more and more knowledge about available products and services, and increasingly require high quality at lower costs. In addition, the evolution of retail marketing (e.g. 24-hour shops, personal deliveries, e-shops, etc.) creates the demand of more efficient supply chain management in order to satisfy consumer needs.

Businesses need to maintain their competitiveness since the competition is getting relentless. To that end, enterprises turn to the development of their entire supply chains and not only the products themselves. Competition is now between supply chains, rather than between enterprises. One of the main purposes for the establishment of a supply chain is to increase its stakeholder's revenue by minimizing the total cost, as well as the response time for the consumers. Small response times are one of the main customer demands in recent years. It should be also highlighted that integration of organizations has emerged to be an important motivator for the increase of an organization's competitiveness.

The evolution of supply chains over the years was highly dependent on technological evolution and customer needs, as well as on the current market requirements. In Figure 2.1, several types of supply chains that have been developed over the years are illustrated.

The first type of supply chain, the standard supply chain, was designed to meet the customers' needs for standard products that did not require adaptability and resource preservation. Standardized products are products that 


\section{International Journal of Innovations in Engineering and Science, www.ijies.net}

have fixed demand and do not have alterations in their traits or their design. The procurement of raw materials for their production is realized in copious quantities, which created the need for standard suppliers. Later in history, the lean supply chain was developed as an improvement on the standard supply chain.

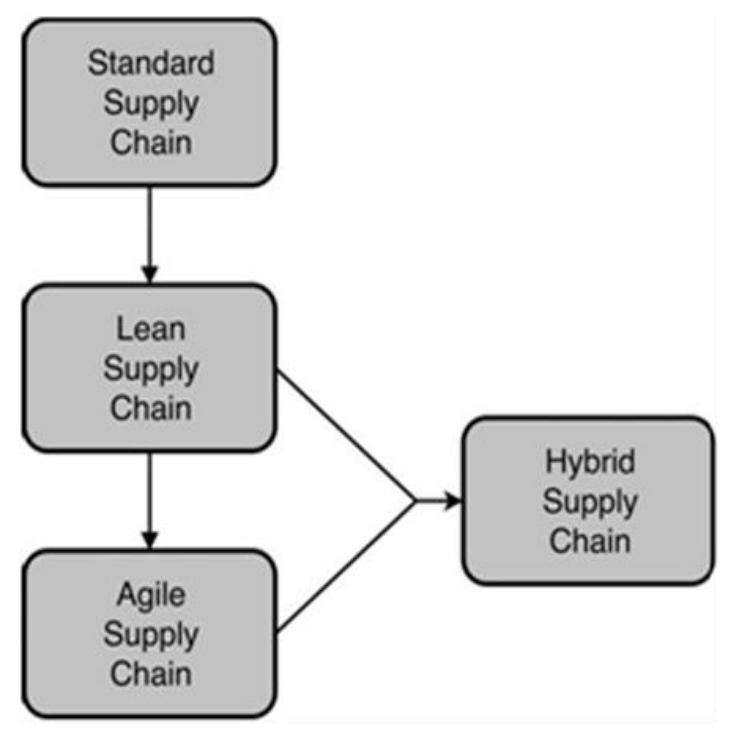

Fig 1 - Evolution of supply chains

The lean supply chain is aiming at ongoing development, mitigation of waste and generally at eradicating all the actions that do not create added value for the consumers. Lean supply chains consider all the life cycle stages of a standard product and attempt to increase the supply chain's efficiency by decreasing the number of steps in the procedure, the time needed and also, all the relevant costs and waste. Also, this type of supply chain can generally satisfy more specialized customer needs and support the production of products in small quantities. The major disadvantage of a lean supply chain is that it is not adaptable to unpredictable situations.

In order to address the deficiencies of these two supply chains, the agile supply chain was developed. An agile supply chain was initially designed to be flexible in unpredictable situations and adaptable to the respective market needs. In addition, agile supply chains can rapidly respond to the unexpected demand of nonstandard, innovative products, and their characteristics may vary depending on individual customer needs.

The combination of the lean and the agile supply chains resulted in the development of the hybrid supply chain to meet the requirements of hybrid products. Hybrid products can be thought as the opposite of standard products, since those are adjustable to the customer preferences. Hybrid supply chains employ techniques such as product postponement in which the product is partially assembled, while its full assembly is pending, depending on customer demand.

\section{From traditional to green supply chain}

Supply chains have been always considered as the procedures used to transform raw materials to finished products which are then delivered to consumers. In the previous sections, it was shown that supply chains have evolved from simple, one-way processes to multi-way, complex networks involving large numbers of stakeholders. Moreover, the latter often show mutually conflicting interests and needs. The evolution of supply chains was always driven by the relevant technological advancements and market conditions. Traditionally, supply chain management focuses mainly on the maximization of consumer satisfaction and in the increase of business revenue and profitability.

However, in recent years, with the emergence of environmental issues, traditional supply chains have been held accountable for generating massive amounts of emissions and waste and resource consumption, contributing to the degradation of the environment and the deterioration of environmental status. Furthermore, supply chains are often accountable for global environmental problems, like global warming, for instance. As a result, environmental sustainability is being intensively integrated in the dominating business practices. To that end, the increasing interest of the stakeholders involved in supply chains on environmental issues led to the development of green supply chains.

The transformation process can be classified in three major groups, categorized by the source of the driving force (Figure 2.2). The key actors in these three models of evolution are the government and private corporations, who initiate the process with different motivations and aspirations as for the outcomes. The top-down approach refers to the attempt of governments to control environmental impacts. This can be accomplished with varying enforcement strength, from rough outlines and safe practice or conduct guidelines to strict legislation and auditing bodies, obligatory conformance to structured environmental management schemes and so on. Governments themselves are subject to control by citizens, and also by international organizations that audit environmental data globally. Accountability to these stakeholders, besides national strategic planning, is a key internal motivator in the top-down approach. Enablers and Barriers of green supply chains, ones that analyses the desired outcomes 


\section{International Journal of Innovations in Engineering and Science, www.ijies.net}

and also the negative side effects of opting to drive the transformation by means of a top-down approach, are further analysed. In general, government-issued mandates are characterized by less innovation potential, stringent limits, inflexible rules and inherently high costs covered ultimately by the citizens. However, it should be highlighted that the environment is often regarded as a priority for governments, even sometimes at the cost of introducing counter-productive measures. Private corporations, under certain circumstances, are also highly interested in planning and implementing green strategy. In the case of private initiatives, the approach is labelled as bottom-up, indicating that corporations are the major drivers of change and innovation. The internal motivators of this endeavour vary from competitors' performance to corporate mission compliance. In case that all internal motivators are analysed in depth, a common financial constituent emerges, as is expected in the case of for profit private corporations. Analogous to governments' accountability to international bodies and citizens, corporations also are accountable to various stakeholders. One obvious group of stakeholders are shareholders, as well as suppliers and customers that are financially affiliated to corporate activities.

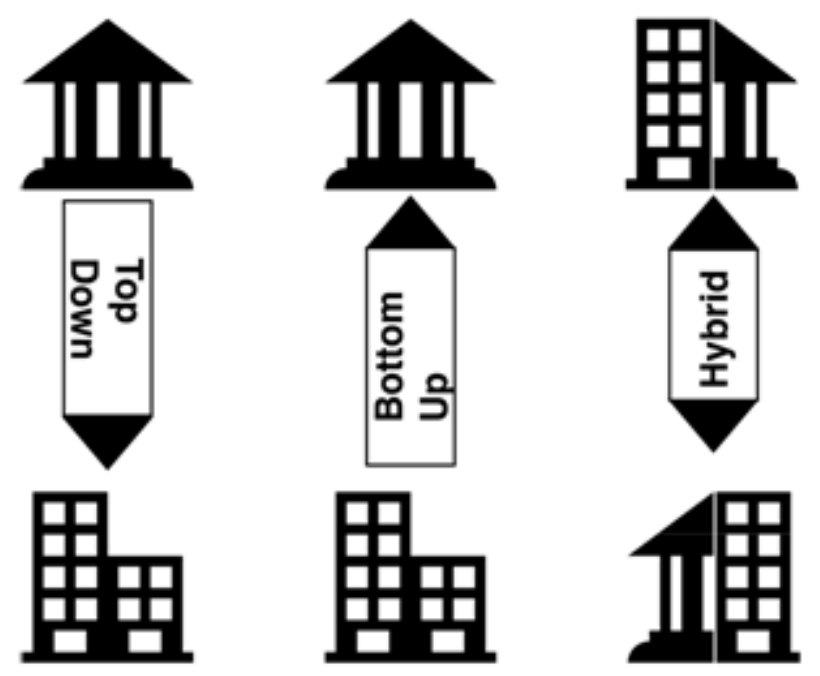

Fig 2-Top-down, bottom-up and hybrid transformation

These actors impose certain demands on the organizations and influence the operations at all levels, even though they have different and conflicting priorities. On top of this situation, corporations also included society in their actor network by adopting and implementing the concept of corporate social responsibility (CSR). In the latest iteration of CSR, environmental issues emerged as a defining force compiling in a single framework3 the three core elements and their aims to an effective business tool, as illustrated in Figure 2.3. Whether CSR is considered as an altruistic notion or as a strategic method to influence and shape public opinion, the environmental performance of corporates engaged in this course of action is noticeably and measurably improved. The driving factors of implementing a green strategy are in real-world conditions an array of intents and expected outcomes, covering the needs of a corporation to operate at minimum cost and maximum profitability, to altruistically reimbursing part of their earnings to the local community and, to some extent, to the global community also.

In addition to direct financial performance, indirect and preventative economic strategies are also in effect when CSR is implemented. Corporations are innately more flexible and sensitive to changes in their operating ecosystem; therefore they tend to be one step ahead of government policies. Moreover, by regularly reviewing environmentally related issues and technologies, they sustain this competitive advantage. Using these intangible assets, corporations are avoiding costly and operations-interruptive occurrences of government interference through mandates that need to be met. They also harness and employ the innovative interorganizational potential, while at the same time are positively predisposed to externally driven innovation. Market share is a key performance index of any for profit organization. In this light, CSR is aligned to this need by catering to the needs of "green consumers", an emerging and growing market group.4 This market section assesses value of products not only by

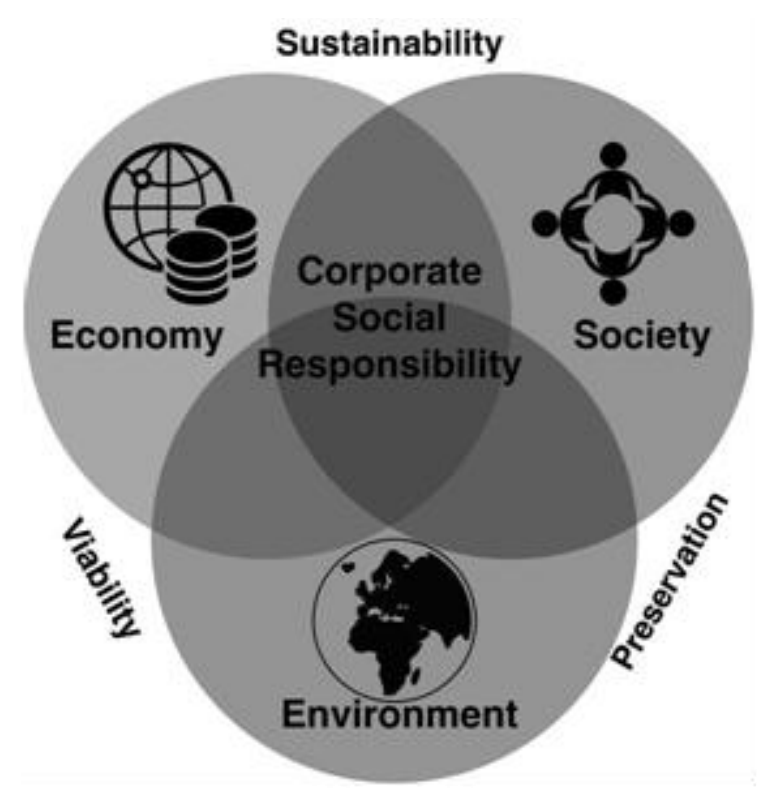

Fig 3 - Corporate social responsibility elements 


\section{International Journal of Innovations in Engineering and Science, www.ijies.net}

financial and feature/functional performance, but also by environmental performance. The added value of a green product is translated in higher status and acceptance among their peers and also as personal fulfilment, since environmentally safe practices have become an essential part of personal value systems in recent decades.

A mixture of both approaches is the most common occurrence in most cases. Such a strategy proposes a more realistic view, combining the advantages of each sector, public and private, to compile a system that is both flexible and stern. As reality suggests, legislation and practice are communicating vessels, both influencing each other. Therefore, the government can benefit from data supply of industries and their voluntary initiative to comply to guidelines and legislation and the private sector has the chance to be part of the public policy setting stakeholders. Furthermore, communication between the two sectors provides the ground to shatter pre-conceptions and facilitate productive dialog that holds the potential to formulate innovative solutions. Being able to synthesize frameworks that cater to the needs of both sectors also ultimately promotes social wellbeing.

\section{IV- PARADOXES IN GREEN SUPPLY CHAIN}

Although there are numerous advantages in redefining a conventional supply chain and evolving it to a green supply chain management model, there are issues that should be dealt with cautiously. Corporate social responsibility can influence positively in terms of environmental performance and assist corporations to sort options by their green potential and impact. However, there are still other significant influences involved in a corporate environment. It should not be ignored that for-profit organizations have as a primary goal - often a single goal in practice - to produce profit. Therefore, their actions and decisions need to be made in accordance with this core strategic goal, often neglecting other parameters like environmental degradation. Cost is a decisive factor for any industry. To that end, practically every business activity triggers a series of events that entail this variable. In the case of green supply chains, improvements in packaging and reducing waste flows improve the performance indexes significantly, with a noticeable effect on cost as well, albeit that some of these costs are actually part of a concealed move of externalizing costs and exacerbating pressure on the environment. Stakeholders involved in the supply chain recognize and enjoy the benefits of reduced costs, while at the same time intentionally or unintentionally ignore environmental considerations. Issues regarding environmental impact have become more popular, and the share of citizens - and consequently, officials who promote green practices rises. However, the costs need to be assumed and governments are pressured to introduce legislation, assigning these costs to corporations. Environmental policies focusing on private personal transportation and vehicles ignore an active and widespread industry that contributes significantly to impacts to the ecosystem. It is a question of system examination boundaries that defines the positive or negative contributions of the activities entailed in the supply chain.

Supply chain strategies that have become common practice in many industries work counter to environmental safe practices. Just in time (JIT) and door to door (DTD) are both practices that introduced great flexibility and agility to the supply chain, but can exacerbate significant pressure on emissions, land use and waste production. As infrastructure needs to be developed to accommodate the increased traffic, the benefits from high environmental performance are diluted by the increase of side effects. Similar phenomena also appear due to the increase of the efficiency level of transportation. Rising efficiency reveals new opportunities in the solution space for optimized production allocation. This has enabled the spatial disaggregation of production and consumption, and brought forth longer kilometer-to-ton ratios and increased packaging requirements, negating the positive effects. In turn, the demand for transportation increases and the positive effects of technological methodical advances are negated. The case of DTD similarly increases emissions, demonstrating that besides the intensification of transportation work, the profile of usage also creates changes in an adverse way.

Reliability is also crucial for supply chain systems, since their complexity level makes them susceptible to a wide array of possible fault sources. To ensure a high reliability rate, system planning tends to favour solutions that do deliver the desired outcome, irrespective of their performance in other fields, that is, green key performance indexes. Unfortunately, in most cases, the solutions that are characterized by increased reliability for example, air and truck transportation - are the least friendly in terms of their environmental performance.

The increase of e-commerce sales channels, in retail but also in business-to-business (B2B) uses, contributed to the significant increase of the share of road transportation. Required are also extensive warehousing 


\section{International Journal of Innovations in Engineering and Science, www.ijies.net}

facilities located adjacent to metropolitan cities, those being the main recipient of products and services procured through this channel. Although the virtualization of brick and mortar shops is considered to bring noteworthy savings of physical resources, the actual functions accompanying trading have migrated from a physical reference point, the shop, to the home or office; that is, the customer.6 Thus, economies of scale are no longer applicable and the impact on traffic, for example, is becoming strong. Considering also that the concentration of activities is high in already congested areas, the negative effect is multiplied.

Warehousing support for all these activities and their novel modes of operation is reduced since the bulk volume of products is on the move. The energy demands and resource usage of storing products in warehouses in contrast to transporting them from production sites or distribution hubs to the consumers - are higher and bring forth severe environmental impacts, considering the previously mentioned factors. The balance of production rates, warehoused goods and logistics needs to optimize cost-profit variables and, in the case of green models, environmental key performance indexes. Meeting all these requirements at optimized levels is virtually impossible. Therefore, endless approaches and models are practically proposed.

\section{V- MANUFACTURING CHRONOLOGY}

\section{Agrarian Period}

The advent of supply chain support for manufacturing occurred long before the term was coined in the 1980s. Artisans represented some of the first innovators of products required by customers. Their production shops consisted of relatively small, family-oriented (organic) firms with flat hierarchies. Limited product inventory necessitated long lead-times, relatively low production volume, and a high level of product quality, requiring a moderately-high degree of skill from craftsmen (Skinner, 1985). Workers typically experienced good job satisfaction, interfaced routinely with customers, and actively participated in both product design, and completion. In this setting, demand depended on repeat customers and referrals based on product quality. Reuse of materials took place with very little waste generated. Suppliers consisted of select firms with close working artisan relationships. Consumers tended to reside within close proximity, accepted lengthy lead-times for orders, and possessed high levels of product satisfaction. Industrial revolution (Table 1) arrived when technology facilitated a change from a craft-based society to an industrial one (Skinner, 1985). During this era the establishment of high-volume production with capitalintensive use of machinery and assembly lines utilizing command and control logic took place (Nahm \& Vonderembse, 2002). Geographic regions shifted from agrarian to industrial. A corresponding growth in the domestic market enabled firms to mass produce standardized products at a lower cost, thriving in a homogeneous national market where all competitors had access to similar resources and supplies. As the supply of manufactured goods expanded, there was a corresponding increase in demand from consumers. However, product selection was reduced in scope (Nahm $\&$ Vonderembse, 2002), with a greater emphasis on price and product availability. Market segments were large and stable. Leading manufacturing firms focused on economies of scale, efficiency, and the reduction of operating costs, while specializing in one product at a time, which resulted in the use of standard supply chains. These firms usually had vertical hierarchies, with established inorganic (mechanistic) structures (Skinner, 1985). Manufacturers typically produced standardized products in mass volume with somewhat narrow product lines, long production runs, and greater lengths of time required for equipment changeover for new products. Minimization of waste was based on economics with little/no attempt to reduce environmental pollution resulting from manufacturing (Sarkis et al, 2011). Suppliers were viewed as non-integral and multiple supplier sources were sought to keep competition strong and margins low. Confronted with rapidly changing market conditions from both customer and supplier perspectives, firms faced a paradigm change from industrial systems (focusing on mass production and reduced cost) to post-industrial systems (focusing on quick response for a variety of high-quality products, with varying customer demands).

\section{Post-Industrial revolution}

As the economy shifted from industrial to postindustrial due to improvements in technology (Table 1), the scope of products expanded and the man As the PostIndustrial Revolution progressed, enhanced consumer knowledge facilitated corresponding increases in both turbulence and complexity in the market (Huber, 1984). Societies became more affluent and modernized and consumers became more discriminating and demanding (Doll \& Vonderembse, 1991), seeking lower cost, better quality, enhanced availability, and greater product 


\section{International Journal of Innovations in Engineering and Science, www.ijies.net}

variety. Consequently, horizontal and vertical integration, along with flexible manufacturing technology (FMT), and lean/time-based manufacturing practices evolved ( $\mathrm{Tu}$ et al, 2001). Efficiency no longer dominated the efforts of competing firms and consumer expectations extended beyond cost, quality, and responsiveness (Duclos et al, 2003; Moore \& Babu, 2008; Pagell \& Wu, 2009). Supply chain complexity increased where competition no longer occurred between large individual firms, but amongst supply chains themselves ( $\mathrm{Li}$ et al, 2005). Adjustments enabled firms to modify their processes to accommodate changes, including short life cycles, and differentiated products (Moore \& Babu, 2008; Nemetz \& Fry, 1988; Vonderembse et al. 1997). These expansive changes established the foundation for transition of manufacturing towards green supply chains. Manufacturing base extended from national/near shore to global. Firms competed in heterogeneous global markets while competitors had access to a variety of resources and strategies (Vonderembse et al. 1997). Market segments were both narrow and constantly changing due to increased uncertainty. New products were introduced with greater speed in addition to comparatively shorter product life cycles. In order to enhance stability, leading companies focused on broadening their portfolios by seeking more expansive ranges of products, along with short production runs and relatively quick change-over time required for product switches (Nahm \&Vonderembse, 2002). During this period Lean, Agile, and Hybrid supply chains emerged (Moore \& Babu, 2008; Sarkis et al 2011). In order to accommodate increased complexity, lean/time-based manufacturing practices (TBMP) occurred enabling firms to eliminate waste, increase speed and enhance flexibility establishing the foundation for customization of responsiveness, cost-effectiveness, and demand volume adjustment (Tu et al, 2001). Economies of scale took a secondary position, while those of scope became one of the main drivers for manufacturing a wide variety of products, quickly and economically to meet customer demands. Firms had more flattened hierarchies with organic structures. The view of suppliers changed from one of a cost burden necessity to an extension of the manufacturing process and integral sustainability component.

Table 1 Manufacturing Chronology

\begin{tabular}{|c|c|c|c|c|c|c|c|}
\hline $\begin{array}{l}\text { Time } \\
\text { Frame }\end{array}$ & Era & $\begin{array}{c}\text { Supply Chain } \\
\text { Type }\end{array}$ & Firm Characteristics & $\begin{array}{l}\text { Mfg. } \\
\text { Focus }\end{array}$ & Env. Focus & Technology & References \\
\hline Before 1780 & Agrarian & Standard & $\begin{array}{l}\text { Small, organic, horizontal } \\
\text { hierarchy, depended on quality } \\
\text { of product to sell. }\end{array}$ & $\begin{array}{l}\text { Economy } \\
\text { of Scope }\end{array}$ & $\begin{array}{c}\text { Tendency to reuse } \\
\text { all materials }\end{array}$ & $\begin{array}{c}\text { Agrarian, Craftsman, } \\
\text { manual }\end{array}$ & Skinner, 1985 \\
\hline $1780-1840$ & \multirow{5}{*}{$\begin{array}{l}\text { Industrial } \\
\text { Revolution }\end{array}$} & \multirow{5}{*}{$\begin{array}{l}\text { Standard shifting } \\
\text { towards Lean }\end{array}$} & $\begin{array}{l}\text { Greater production achieved, } \\
\text { but constrained by limitations } \\
\text { of small-scale transportation, } \\
\text { limited power, and flexibility. }\end{array}$ & \multirow{4}{*}{$\begin{array}{l}\text { Economy } \\
\text { of Scale }\end{array}$} & \multirow{4}{*}{$\begin{array}{l}\text { Minimal reflection } \\
\text { on adverse } \\
\text { environ. effects } \\
\text { of waste. Main } \\
\text { focus on reduction } \\
\text { of waste from } \\
\text { an economic } \\
\text { standpoint }\end{array}$} & $\begin{array}{l}\text { Harnessing of water } \\
\text { and steam energy } \\
\text { enabled mechanization }\end{array}$ & \multirow{2}{*}{$\begin{array}{l}\text { Skinner,1985; } \\
\text { Nelson, } 1975\end{array}$} \\
\hline $1840-1850$ & & & $\begin{array}{l}\text { Advances in metalworking and } \\
\text { production enhanced flexibility }\end{array}$ & & & \begin{tabular}{|c|} 
Interchangeable parts \\
developed to enable \\
quick repair during \\
production.
\end{tabular} & \\
\hline $1850-1890$ & & & $\begin{array}{l}\text { Mass production where } \\
\text { efficiency dominates. } \\
\text { Substantial advances } \\
\text { in technology }\end{array}$ & & & $\begin{array}{c}\text { Massive, rapid } \\
\text { changes in technology. } \\
\text { High-volume } \\
\text { production with } \\
\text { interchangeable parts. }\end{array}$ & $\begin{array}{l}\text { Skinner, 1985; } \\
\text { Chandler, 1977; } \\
\text { Nelson, } 1975\end{array}$ \\
\hline $1890-1920$ & & & $\begin{array}{l}\text { Industrial expansion in size, } \\
\text { variety, complexity, diversity. }\end{array}$ & & & $\begin{array}{l}\text { Systematic controls } \\
\text { focusing on complex } \\
\text { mkts. }\end{array}$ & Skinner, 1985 \\
\hline $1920-1960$ & & & $\begin{array}{l}\text { Increasing consumer } \\
\text { requirements in latter period }\end{array}$ & $\begin{array}{l}\text { Economy } \\
\text { of Scale } \\
\text { and Scope. }\end{array}$ & $\begin{array}{l}\text { Growing need } \\
\text { recognized }\end{array}$ & $\begin{array}{c}\text { Automation took place } \\
\text { in late } 1950 \mathrm{~s} .\end{array}$ & Skinner, 1985 \\
\hline
\end{tabular}




\section{International Journal of Innovations in Engineering and Science, www.ijies.net}

\begin{tabular}{|c|c|c|c|c|c|c|c|}
\hline $1960-1980$ & & $\begin{array}{l}\text { Lean, Agile, } \\
\text { Hybrid }\end{array}$ & $\begin{array}{l}\text { Consumer demand increases } \\
\text { for variety, timeliness and } \\
\text { cost, driving greater market } \\
\text { complexity }\end{array}$ & Economy & $\begin{array}{c}\text { US EPA } \\
\text { established } \\
\text { followed by strong }\end{array}$ & $\begin{array}{l}\text { New systems - Just- } \\
\text { in-Time (JIT)/Kanban } \\
\text { greatly improve } \\
\text { product quality and } \\
\text { delivery }\end{array}$ & Skinner, 1985 \\
\hline $\begin{array}{c}1980 \text { - } \\
\text { Present }\end{array}$ & $\begin{array}{l}\text { Post } \\
\text { Industrial } \\
\text { Revolution }\end{array}$ & $\begin{array}{l}\text { Agile, Hybrid, } \\
\text { then a shift } \\
\text { towards Green }\end{array}$ & $\begin{array}{l}\text { System design shifted towards } \\
\text { consumer needs and paradigm } \\
\text { changes from linear/sequential } \\
\text { to parallel, integrative, and } \\
\text { systematic. Move to integration } \\
\text { across production chains, with } \\
\text { flat organizations. Automation } \\
\text { used only for added value. }\end{array}$ & $\begin{array}{l}\text { and Scope } \\
\text { with focus } \\
\text { on latter }\end{array}$ & $\begin{array}{l}\text { focus on pollution } \\
\text { prevention and } \\
\text { mitigation strategy } \\
\text { in each state }\end{array}$ & $\begin{array}{c}\text { Info. exchange } \\
\text { becomes critical as } \\
\text { single mfg. syst. } \\
\text { produces large } \\
\text { variety of different } \\
\text { products. Integration } \\
\text { more important than } \\
\text { automation. }\end{array}$ & $\begin{array}{c}\text { Skinner, 1985; } \\
\text { Petrie, 1992; } \\
\text { Susman, 1992; } \\
\text { Vonderembse1997; } \\
\text { Rao, \& Holt, 2005; } \\
\text { Sarkis et al, } 2011\end{array}$ \\
\hline
\end{tabular}

\section{VI-CONCLUSION}

In this paper, we have focused on how supply chains have evolved from ancient times to the modern green supply chains we have today. Different types of supply chains were presented, and the transition from traditional/ conventional supply chains to green supply chains was discussed. Moreover, this paper explained the motivators of this transition and identified the paradoxes in green supply chains. It motivated the need for improvements in supply chain management and environmental sustainability being integrated in modern business strategy. It also presents supply chains at a global scale introduce corporate social responsibility in their business strategies.

\section{VII-FUTURE RESEARCH}

Focus of the current study was on supply chain emergence and green supply chain management, same research can be conducted relevant to green supplier and its selection process in details. Green supplier initiates the green supply chain process, therefore of vital importance for the businesses practicing GSCM. Future research can be conducted on sustainability and green supply chains with respect to Resource Based View (RBV) which states that organizations with rare, valuable, non-substitutable and inimitable resources have more chances of sustainability and competitive advantage over others.

\section{REFERENCES}

[1] Chiu, (Anthony) Shun Fung, Tan, R. R. \& SiribanManalang, A. B. Sustainable consumption and production for Asia: Sustainability through green design and practice. J. Clean. Prod. 40, 1-5 (2014).

[2] Doll, W.J. \& Vonderembse, M.A., 1991, the evolution of manufacturing systems: Towards a post-industrial enterprise. International Journal of Management Science, 19(5), pp. 401-411.

[3] Duclos, L.K., Vokurka, R.J., \& Lummus, R.R., 2003, A conceptual model of supply chain flexibility, Industrial Management and Data System, 23(3) pp. 113-121.

[4] Easterby-Smith, M., Thorpe, R., Lowe, A. (2002). Management Research - An Introduction. London: Sage Publications.

[5] Engels D. Alexander the Great and the logistics of the Macedonian army, 1st edition. (University of California Press, 1978).

[6] Huber, G.P., 1984, The Nature and design of postindustrial organizations. Management Science, 30, pp. 928-951

[7] Li, S., Rao, S.S., Ragu-Nathan, T.S., Ragu-Nathan, B., 2005, Development and validation of a measurement instrument for studying supply chain management practices, Journal of Operations Management, 23, pp. 618-641

[8] Meredith, J. (1993). Theory building through conceptual methods. International Journal of Operations \& Production Management, 13, 3-11.

[9] Moore, D., \& Babu, A.S., 2008, Perspectives, practices, and future of supply chain flexibility, International Journal of Business Excellence, 1(3), pp. 302-336

[10] Nahm, A.Y., \& Vonderembse, M.A., 2002, Theory Development: An industrial/post-industrial perspective on manufacturing. International Journal of Production Research, 40 (9), pp. 20672095.

[11] Nemetz, P.L. \& Fry, L.W., 1988, Flexible manufacturing organizations: Implication for 
Vol. 6, No. 1, 2021, PP. 12-21

\section{International Journal of Innovations in Engineering and Science, www.ijies.net}

strategy formulation and organizational design. Academy of Management Review, 13 627-638.

[12] Pagell, M., \& Wu, Z., 2009, Building a more complete theory of sustainable supply chain management using case studies of 10 exemplars. Journal of Supply Chain Management, 45(2), pp. 37 $-56$

[13] Searcy, D.L. and Mentzer, J.T. (2003). A framework for conducting and evaluating research. Journal of Accounting Literature, 22, 130-167.

[14] Skinner, W., 1985, The Taming of lions: How manufacturing leadership evolved 1780-1984. In K.B. Clark, R. Hayes and C. Lorenz (eds.), the Uneasy Alliance: Managing the Productivity Technology Dilemma (Boston: Harvard School Press), pp. 63113

[15] Tu, Q., Vonderembse, M. \& Ragu-Nathan, T.S., 2001, the impact of time-based manufacturing practices on mass customization and value to customer. Journal of Operations Management, 19, pp. 201-217

[16] Vonderembse, M.A., Ragunathan, T.S., \& Rao, S.S., 1997, A postindustrial paradigm: To integrate and automate manufacturing. International Journal of Production Research, 35, pp. 25792599.

[17] Wilkerson, T. (2005). Can One Green Deliver Another? Harvard Business School Publishing Corporation

[18] Wu, H.J. and Dunn S. C. (1995). Environmentally responsible logistics systems. International Journal of Physical Distribution \& Logistics Management, 25, 20-39

[19] Wu, J., Dunn, S., \& Forman, H. (2012). A study on green supply chain management practices among large global corporations. Journal of Supply Chain and Operations Management, 10(1), 182-194.

[20] Yazdani, M. (2014). "An integrated MCDM approach to green supplier selection." International Journal of Industrial Engineering Computations, 5(3), 443-462. 